\title{
SLAM Family Member 6
}

National Cancer Institute

\section{Source}

National Cancer Institute. SLAM Family Member 6. NCI Thesaurus. Code C105057.

SLAM family member 6 (332 aa, $\sim 37 \mathrm{kDa}$ ) is encoded by the human SLAMF6 gene. This protein acts as a coreceptor in the process of natural killer cell activation. 